\title{
EDITORIAL \\ PERSPECTIVAS DIASPÓRICAS: MEMÓRIAS, ENCONTROS E RESISTÊNCIAS
}

\author{
Diasporic perspectives: memories, encounters and resistances
}

\author{
Roberto Marinucci* \\ Maria do Carmo dos Santos Gonçalves**
}

O conceito de diáspora dialoga com outras categorias que integram o campo de estudos sobre migrações e refúgio. Nas últimas décadas, passou por um processo de ampla difusão, abarcando fenômenos onde se constata, além da dispersão, dinâmicas auto organizacionais de grupos e coletivos de pessoas em mobilidade. De acordo com Tölölyan (2011), as enormes mudanças materiais e discursivas ocorridas nas últimas décadas, influenciaram "tanto a quantidade de diásporas globais quanto o espectro e a diversidade do novo campo semântico que habita o termo 'diáspora'" (Tölölyan, 2011, p. 51). As diásporas são por sua natureza e características um fenômeno que coloca em relevo o aspecto coletivo das migrações a partir de um amplo leque de experiências de deslocamento, permanência e circulação de grupos e comunidades dispersos. Ainda de acordo com Tölölyan (2011), os fatores que influenciam no surgimento das diásporas são sobre determinados e poderiam ser identificados como materiais, demográficos, administrativos, discursivos e ideológicos.

Tais fatores identificam-se por uma acelerada imigração para o mundo industrializado; pelo aparato legal, político, administrativo e ideológicocultural do país receptor no trato da imigração; pela existência de organizações institucionalizadas na pátria nacional e o alcance dessas no acompanhamento aos imigrantes; pela proporção de imigrantes em relação à população autóctone; pela questão da diferença racial e a incompatibilidade real ou percebida tanto

Editor-chefe da Revista REMHU, Centro Scalabriniano de Estudos Migratórios (CSEM). Brasília DF, Brasil. E-mail: remhu@csem.org.br. Orcid: https://orcid.org/0000-0002-2042-2628.

** Doutora em Ciências Sociais pela Pontifícia Universidade Católica do Rio Grande do Sul (PUCRS). Brasília, DF, Brasil. E-mail: diretora@csem.org.br. Orcid: 0000-0002-2740-9856. 
pelas comunidades migrantes em relação à população autóctone, assim como dos nacionais em relação aos estrangeiros.

Para Safran (1991), o conceito de diáspora estaria delimitado pelas características observáveis nos grupos formados por pessoas em mobilidade. De modo geral, se diz desses grupos que seus membros compartilham um processo de dispersão de um "centro" específico, que pode ser materializado por uma pátria, país ou nação, mas também pode ser de ordem subjetiva, como um local religioso simbólico. As diásporas se formam a partir de dinâmicas centrífugas para regiões estrangeiras ou "periféricas". As formações diaspóricas também conservam "uma memória coletiva, uma visão ou mito sobre sua pátria de origem - sua localização física, sua história e suas conquistas" (Safran, 1991, p. 32). Tal compartilhamento, seja objetivo e/ou afetivo reúne essas pessoas dispersas em torno de uma mesma percepção de origem comum. Sendo assim, a manutenção dessa memória garante seu alinhamento em torno de objetivos comuns, direcionados à sua manutenção e identidade coletiva.

Outra característica das diásporas seria o compartilhamento da crença e/ou da experiência concreta de não aceitação na sociedade anfitriã. Hodiernamente esse aspecto vem sendo reforçado pelo incremento da hostilidade e da xenofobia direcionada a grupos específicos de migrantes em diferentes contextos mundiais. A noção de não-aceitação ou a ausência da hospitalidade reforçam o sentimento de não pertencimento ao local onde se encontram, gerando um tipo isolamento. Quase como derivação de um contexto hostil nas sociedades de recepção, as diásporas passam a reforçar a ideia da sua terra ancestral como seu lar verdadeiro e ideal, assim como colocam o movimento de retorno a esse local, aguardando as condições ideais para isso.

Outro aspecto que marca as formações diaspóricas é o comprometimento coletivo com a conservação ou a restauração de sua pátria original, com sua segurança e prosperidade, movimento que implica a busca constante por incidência, bem como o desejo de continuar se relacionando pessoal e indiretamente com a pátria original sendo que "a consciência e solidariedade étnico-comunitária são definidas de maneira importante por essa relação" (Safran, 1991, p. 92). Cohen (2008) acrescenta a essas características a criatividade que acompanha as diásporas, o que as tornam, inclusive, fatores de desenvolvimento das sociedades de acolhida, dada a sua agência. As diásporas se tornam elas mesmas pontes importantes de interlocução entre as sociedades de origem e de destino de migrantes e refugiados.

Embora possamos afirmar com certa margem de segurança que para considerarmos um grupo como diaspórico deveríamos, em alguma medida, levar em consideração essas delimitações teóricas, também é verdade que se trata de um campo dinâmico que nos impele a olhar para os fenômenos empíricos que os configuram de modo que se possa avançar cada vez mais na compreensão sobre 
as formações diaspóricas e sua contribuição ao campo de estudos das migrações e refúgio.

Assim sendo, olhando para casos empíricos que embasam os artigos que compõem o Dossiê deste número da Revista, percebemos que a diáspora não é produto automático de uma ampla emigração. É algo "construído" e, por vezes, "em construção". Em alguns casos, entidades governamentais podem incentivar a consciência diaspórica por finalidades políticas (voto no exterior) ou econômicas (incentivar remessas, o consumo de produto do país de origem). Em outros, as diásporas podem se construir em oposição aos governos dos países de origem, principalmente quando o deslocamento da maioria da população é uma emigração forçada. É nesta perspectiva que é elaborado o artigo de Beatriz Padilla e Magdalena López, que abordam o recente deslocamento massivo de venezuelanos e venezuelanas com foco em três países de recepção: Argentina, Portugal e EUA. As autoras se interrogam sobre a possível constituição de uma "diáspora". De fato, há pelo menos dois elementos que unem as pessoas venezuelanas no exterior: a experiência comum da crise no país de origem e, ao mesmo tempo, a formação de redes de ajuda mútua. Em outros termos, é "una diáspora en vías de institucionalización y consolidación", onde o compartilhamento de experiências de vida acaba consolidando um sentido comum, para além das diferenças de gênero, classe social, idade ou grau de instrução.

No fundo, para além do passaporte, é o compartilhamento de experiências e vivências que cria aqueles vínculos típicos das diásporas, sendo que, em alguns casos, essa prática dá origem a organizações de migrantes, com estruturas mais ou menos institucionalizadas. É este o tema focado por José Carlos Marques e Pedro Góis que apresentam uma pesquisa sobre associações de portugueses no exterior. A reflexão aponta para várias questões: os grupos associativos não se limitam a estabelecer um vínculo entre país de origem e diáspora, mas, com frequência, promovem também interações entre diásporas e países de acolhida; a multifacetada tipologia dessas associações revela a heterogeneidade em termos de estruturas, interesses e objetivos, o que mostra que as diásporas não podem ser focadas como algo uniforme ou monolítico; finalmente, a recente difusão de "Digital Diaspora Networks", com focos e características diferentes, mas acomunadas pela utilização das novas tecnologias de comunicação e pela abrangência transnacional, aponta para uma dinamicidade e criatividade das diásporas, influenciada inclusive pelos inevitáveis intercâmbios geracionais e suas implicações.

A heterogeidade das pessoas migrantes na diáspora é também um dos aspectos realçados por Rose Jaji em seu trabalho sobre formação e consolidação das diásporas Zimbabuanas na Alemanha e na África do Sul. Diaspora is fluid and diverse, sustenta a autora, que apresenta algumas tipologias de vinculação de migrantes com os países de origem e chegada. Nessas diferentes tipologias, há vários fatores que incidem, como a temporalidade da migração, as causas, as 
perspectivas, as políticas migratórias, as relações familiares, bem como a conjuntura dos países envolvidos. De acordo com Rose Jaji o projeto migratório das pessoas migrantes Zimbabuanas tende a ser alterado no decorrer do tempo, dependendo justamente dos fatores supracitados. No fundo, o artigo, além de ressaltar a diversificação e a evolução diacrônica das pessoas que vivem nas diásporas, evidencia também como nem sempre o indivíduo migrante se autocompreende e atua como "diáspora", ou seja, com estritos vínculos com o país de origem e com práticas transnacionais.

Há casos também em que grupos diaspóricos podem atuar de longe a fim de promover mudanças no país de origem, sobretudo em contextos marcados pela fuga do país e busca de refúgio. A diáspora, neste caso, pode representar uma "memória histórica" de acontecimentos esquecidos ou até censurados. Este é o caso estudado por Alessandra Ciurlo em relação à diáspora colombiana na Europa. A autora reflete sobre o tema a partir de algumas produções artísticas ("artivismo"). Na interconexão entre arte, memória e diáspora ela mostra como a vinculação com o país de origem pode ser de tipo político, visando a conscientização sobre os episódios de violência ocorridos e a sensibilização acerca dos dramas sofridos pelas vítimas refugiadas do conflito armado ou pela população em geral. A diáspora, em outras palavras, pode contribuir com seu "artivismo" para a reelaboração de uma memória coletiva a partir da narrativa das vítimas das violências e, desta maneira, contribuir para um real processo de paz.

Permanecendo no âmbito artístico, a música também pode ser fonte de memória e ato de protesto: memória da própria terra e denúncia das violações sofridas pelas pessoas migrantes. Pode ser também um recurso de afirmação identitária, bem como um caminho para o encontro e o diálogo, uma ponte para se conectar com quem não pertence à própria comunidade étnica. Sobre essa questão é focado o artigo de Kelvin Venturin e Maria Elizabeth Lucas, que abordam o tema da "diáspora musical senegalesa" no sul do Brasil. A preocupação dos autores é focar como nas diásporas, mediante a produção musical, pessoas migrantes "desenvolvem redes culturalmente produtivas e conectadas à sua terra natal e em dialogia com um novo contexto sociocultural". O assim chamado "rap de conexão" permite a interlocução e interação com quem não pertence à diáspora, favorecendo inclusive a produção de novas identidades e subjetividades. Mais uma vez, a reflexão atenta para a necessidade de se pensar as diásporas não como realidades essencializadas ou como meras reproduções do "nacional" em terra estrangeira, e sim como realidades dinâmicas, relacionais e criativas - até sincréticas ou híbridas.

Finalmente, Henri Acselrad, no artigo final do dossiê, aponta por mais um aspecto da vida diaspórica: o papel dos objetos. Trata-se dos objetos-memória, que reconectam as pessoas migrantes com a terra e a cultura de origem; os objetos-sujeito, que dão voz a quem já não pode mais falar; os objetos-ponte, 
que criam as condições e as gramáticas para o encontro e o diálogo com a alteridade. No caso específico, o autor reflete sobre o assunto a partir dos livros em língua yiddish, trazidos para o Brasil pela imigração judaica, e a constituição da Biblioteca Scholem Aleichem no Rio de Janeiro. Esses livros, segundo o autor, "carregam as marcas dos lugares em que foram produzidos e onde circularam, de sua concepção e manuseio, das formas técnicas e estéticas de sua construção e disposição nos locais de reinserção dos migrantes". Eles são livros migrantes, escritos por migrantes, com protagonistas migrantes e numa língua, o yiddish, que poderíamos definir "desterritorializada" ou, de qualquer forma, não atrelada a um Estado-nação. Assim como a música e outras produções artísticas, os livros também possuem o potencial relacional de "agregar", de vincular o presente, o passado e o futuro, a terra de origem e a terra de chegada - e todas as demais "terras" e "mares" pelos quais circularam. Objetos e produções artísticas fortalecem a diáspora e, inclusive, podem interconectar os grupos diaspóricos presentes em diferentes territórios.

Enfim, os múltiplos olhares dos artigos da revista para diferentes diásporas presentes em vários continentes e espaços socioculturais atestam a pertinência de uma categoria teórica - diáspora - que contribui na reflexão da literatura migratória ao chamar a atenção para as formas de resistências e lutas coletivas de quem, apesar do desterro ou da fuga, mais ou menos forçada, resiste, reconstrói uma identidade e, inclusive, atua de forma transnacional para o desenvolvimento integral da terra de origem.

$* * * *$

Na seção "Artigos" da REMHU 62, José Berríos-Riquelme aborda a problemática da inserção no mercado de trabalho de migrantes venezuelanos qualificados no norte do Chile, ressaltando o impacto das políticas migratórias restritivas e securitárias, que se contrapõem a um discurso oficial focado no respeito dos direitos humanos. De forma específica, o autor destaca as estratégias de inserção e, sobretudo, demonstra como o processo de revalidação dos diplomas é burocrático, oneroso e pouco acessível, obrigando muitos migrantes a assumir postos de trabalho para os quais são super qualificados.

Isac Alves Correia a partir de uma pesquisa realizada no Seridó Potiguar (Rio Grande do Norte, Brasil), busca compreender as diferentes intenções de mobilidade induzidas pela seca entre indivíduos residentes em áreas urbanas. Conforme os resultados da pesquisa, a experiência anterior com deslocamentos, o tempo que o indivíduo permanece fora do domicílio de residência habitual e a jovem idade impactam nas intenções de mobilidade enquanto estratégia de adaptação ao desastre ambiental. O texto ressalta também que a migração é um processo multicausal e que a estiagem influencia, mas não determina a intenção de se deslocar. 
Erika Andrea Butikofer e Eliane Alves da Silva discutem os mecanismos que os imigrantes haitianos utilizam para se estabelecer na periferia de São Paulo, no Brasil, tomando como caso particular Guaianases, distrito do extremo leste da capital paulista. O artigo toma como objeto de estudo a intersecção entre acesso à moradia e ao trabalho com vistas a alcançar o direito à cidade. As autoras realçam a agência das pessoas migrantes, o envolvimento em movimentos sociais, a formação de redes solidárias familiares e, principalmente, de adesão religiosa, o que permite "pensar a condição dos imigrantes para além do registro da falta ou ausência, recuperando os recursos que os mesmos mobilizam ou criam ao se estabelecerem nos locais de destino".

O artigo de Júlia Alves Brasil traz uma análise feita a partir das notícias veiculadas na mídia sobre migração e a pandemia de Covid-19. A autora busca compreender as estruturas semânticas que organizam as representações sociais feitas sobre as migrações e as pessoas migrantes no período em tela. Em geral, diferentemente de outros contextos, o universo migratório não ficou "ancorado" ao tema da criminalidade, mas, relacionado a eventos significativos - à pandemia ou aos protestos e às eleições nos EUA -, foi representado com frequência mediante estereótipos de vitimização ou culpabilização. Ainda assim, cabe destacar que tais "eventos-chave" alimentaram também debates e questionamentos sobre práticas discriminatórias contra migrantes ou outras minorias.

Juan C. Méndez Barquero chama atenção para a complexidade teóricoconceitual da "migração de trânsito" como uma unidade de análise. Para tanto, utiliza o estudo de caso do deslocamento de migrantes extrarregionais (oriundos de Ásia, África e Caribe) em trânsito pela América Central a partir de 2015. O autor parte de uma revisão bibliográfica para mostrar como, apesar de relevante e urgente, a questão da "migração de trânsito" não é ainda suficientemente estudada e utilizada como ferramenta analítica na literatura migratória.

No artigo de Denise Rocío Ganza conhecemos a história de uma família de irmãs italianas que migraram para Argentina, região de Valentín de Alsina em Buenos Aires, a fim de compreender as trajetórias migratórias e de integração na sociedade receptora. O corte metodológico visa focar a subjetividade do grupo pesquisado e o papel determinante exercido por processos de índole social (a Segunda guerra mundial) e familiar, atentando para as normas e as tradições de gênero enquanto fatores essenciais para a compreensão das dinâmicas migratórias.

Na Seção "Relatos e reflexões", Marinês Biasibetti, mscs apresenta alguns resultados de três estudos realizados pela Comissão Episcopal para Migrantes, Refugiados e Deslocados de Moçambique sobre tráfico de pessoas, órgãos e partes do corpo humano. Além das graves consequências, o texto destaca as causas estruturais, culturais e sociais do tráfico humano, que constitui, na atualidade, um dos principais desafios para este país africano. 
A Resenha de Otávio Ávila sobre o livro Estrangeiros Residentes: uma filosofia da migração de Donatella Di Cesare encerra o número da Revista.

Desejamos a todas e todos uma boa leitura.

\section{Referências bibliográficas}

COHEN, Robin. Global Diasporas: An Introduction. Routledge, 2008.

SAFRAN, William. Diasporas in modern societies: Myths of homeland and return. Diaspora: A journal of transnational studies, v. 1, n. 1, p. 83-99, 1991.

TÖLÖLYAN, Khachig. La reconsideración de Diaspora y las diásporas: poder sin Estado en el momento transnacional. In: GOLUBOV, Nattie (ed.). Diásporas: reflexiones teóricas. Mexico: Ed. Universidad Nacional Autónoma de Mexico, p. 51-84, 2011. 